\title{
PSEUDO-HAEMOPHILIA : AN ACQUIRED HAEMORRHAGIC DIATHESIS DUE TO A CIRCULATING ANTICOAGULANT
}

\author{
BY \\ C. HOUGIE \\ From the West London Hospital Medical School
}

(RECEIVED FOR PUBLICATION NOVEMBer 4, 1952)

Recent progress in research on blood coagulation has led to the recognition of an acquired haemophilia-like disease attributable to the presence of a circulating anticoagulant which differs from heparin.

Of the 18 recorded cases of this diathesis, which will be referred to as "pseudo-haemophilia," all but two were associated with some other disease or followed shortly after parturition. A further case is now reported in a previously healthy man aged 82 , and an account is given of the routine and special investigations carried out to establish the diagnosis and determine the nature of the circulating anticoagulant.

\section{Case Report}

The patient, a retired clerk, aged 82 , was admitted to hospital in April, 1952, with massive subcutaneous and intramuscular haemorrhages involving both arms and legs. He had never previously bruised easily and there was no past history of any other haemorrhagic manifestations such as excessive bleeding following dental extractions or cuts. A two-stage prostatectomy had been performed at another hospital five years previously for benign hypertrophy; this operation was uneventful as regards excessive bleeding and duration of convalescence. The patient had never received transfusions or injections of whole blood or blood products. There was no family history of excessive bleeding or bruising.

The patient was well nourished and had been living on a diet containing adequate amounts of fresh vegetables, milk, and meat. Apart from the haemorrhagic phenomena the only physical abnormality on admission was mild osteoarthritis of both knees. The bruising gradually subsided and he was discharged 10 days after admission.

Two days after discharge a small subcutaneous area of bruising became visible on the upper part of the left arm and extended in the course of a few days to involve most of the limb. At this time he also developed a haemarthrosis of the right ankle. Further subcutaneous and intramuscular haemorrhages have occurred and up to the time of writing the patient has never been entirely asymptomatic.

He was treated with cortisone, but this had no apparent effect on the condition and was discon- tinued after a week's course when a total of $1 \mathrm{~g}$. had been given.

Apart from the incapacities and pain caused by the $\tilde{\omega}_{0}$ haemorrhagic manifestations the patient has felt rela-o tively well and is able to get about very much as before his present illness.

\section{General Laboratory Investigations}

A full blood examination gave the following results: white-cell count $8,600 \mathrm{c}$.mm., with a normal ${ }^{<}$ differential count. The red-cell count was $5,000,000 \overrightarrow{0}$ per c.mm., Hb 14.2 g. per $100 \mathrm{ml}$., and erythrocyte $\omega$ sedimentation rate of $5 \mathrm{~mm}$. in one hour (Westergren).

Acid phosphatase was 3.8 units and alkaline phosphatase 13.2 King Armstrong units.

Thymol turbidity was 1 unit.

The Wassermann and Kahn reactions were negative.

The vitamin $C$ saturation test was normal. The $\stackrel{\mathbb{Q}}{\mathbb{Q}}$ calcium level was $11 \mathrm{mg} . \%$. Analysis of plasma pro- $\overrightarrow{\vec{F}}$ teins gave albumin $4.6 \mathrm{~g} . \%$ and globulin $2.3 \mathrm{~g} . \%$.

Urine was normal.

\section{Laboratory Techniques}

Collection of Blood.-Blood was collected by vene-응 puncture and added to $3.8 \%$ sodium citrate in the proportion of 9 parts whole blood to 1 part citrate. 3 The blood was then centrifuged at 2,000 r.p.m. for 15 minutes and the plasma separated for use.

Blood Thromboplastin Generation Test.-This was carried out by the method described by Biggs, Douglas, and Macfarlane (1953).

Two-stage Measurement of Prothrombin.-The technique used has been described by Biggs and $N$ Douglas (1953).

\section{Investigations of Clotting Defect}

The tourniquet test was negative. The plateleto count (Lempert's method) gave 280,000 per c.mm The clotting time (Lee and White method) was $32 \div$ minutes (normal 4 to 10 minutes). The clotting times for capillary blood (Dale and Laidlaw method) was 6 minutes (normal 2 minutes).

The bleeding time (Ivy) was 2 minutes, with fibrino- $\frac{\text { के }}{\mathrm{D}}$ gen $200 \mathrm{mg} . \%$.

The one-stage prothrombin time (human brain $\mathbb{Q}$ thromboplastin) was $15 \mathrm{sec}$. (normal control $15 \mathrm{sec}$.). $\overline{0}$

The two-stage measurement of prothrombin gave a normal result. 
The recalcification times were, for low-spun plasma, 9 minutes (normal up to $2 \frac{1}{2}$ minutes), for high-spun plasma 14 minutes (normal up to 4 minutes).

The two-stage prothrombin consumption test showed gross delay in prothrombin consumption.

The prothrombin consumption index (Merskey, 1950) was $120 \%$.

Factors $V$ and VII.-The normal one-stage prothrombin times excluded deficiency of these factors.

Heparin-like Substances.-An excess of heparinlike substances was excluded by titration of the patient's whole blood with protamine sulphate and toluidine blue.

Antithrombin.- No increase of antithrombin in the patient's plasma compared with that in haemophilic and normal plasma was detected, using a method described by Owen and Bollman (1948).

Inhibitors of Human Brain Thromboplastin.There was no excessive destruction of the thromboplastic activity of human brain thromboplastin when incubated with the patient's plasma (Table I). This fact was learnt by incubating $1 \mathrm{ml}$. of patient's and normal plasma separately with $1 \mathrm{ml}$. of human brain thromboplastin. Samples, $0.1 \mathrm{ml}$., were removed from each incubating mixture at intervals and added to $0.1 \mathrm{ml}$. of normal plasma which was then recalcified with $0.1 \mathrm{ml}$. of $\mathrm{M}-40$ calcium chloride ; the clotting times obtained are recorded.

TABLE I

CLOTTING TIMES

\begin{tabular}{|c|c|c|c|c|}
\hline \multirow{3}{*}{$\begin{array}{l}\text { Type of Plasma } \\
\text { Incubated with } \\
\text { Thromboplastin }\end{array}$} & \multicolumn{4}{|c|}{$\begin{array}{l}\text { Time of Incubation of Plasma- } \\
\text { thromboplastin Mixture }\end{array}$} \\
\hline & 5 Min. & $30 \mathrm{Min}$. & 1 Hour & 2 Hours \\
\hline & \multicolumn{4}{|c|}{ Clotting time in seconds } \\
\hline $\begin{array}{ll}\text { Normal } & \cdots \\
\text { Patient's } & \cdots\end{array}$ & $\begin{array}{l}26 \\
27\end{array}$ & $\begin{array}{l}30 \\
30\end{array}$ & 32 & $\begin{array}{l}40 \\
40\end{array}$ \\
\hline
\end{tabular}

One-stage Prothrombin Times of Patient's Plasma. - These, which were determined using varying dilutions of rabbit or human brain thromboplastin, only differed from those of normal plasma when the brain thromboplastin was diluted to such an extent as to render it relatively impotent; then the clotting times approached the calcium time.

Tests for Circulating Anticoagulants.-These depend on the prolongation of the clotting time of normal whole blood by adding small amounts of the patient's blood. The technique used here was that recommended by Singer, Mond, Hyman, and Levy (1950). In this method $1 \mathrm{ml}$. of whole normal blood of the same blood group as that of the patient is added to $0.3 \mathrm{ml}$. saline and $0.3 \mathrm{ml}$. of the patient's whole blood, and the average Lee and White clotting times determined (Table II).

These results show the presence of a circulating anticoagulant in the patient's whole blood. Further experiments in which $0.3 \mathrm{ml}$. of plasma or serum was added to $1 \mathrm{ml}$. of whole normal blood and the clotting times recorded (Table III) show that both the
TABLE II

CLOTTING TIMES AFTER ADDITION OF SALINE AND PATIENT'S BLOOD TO NORMAL BLOOD

\begin{tabular}{c|c|c}
\hline $\begin{array}{c}\text { Substrate Added to 1 ml. } \\
\text { of Whole Normal Blood }\end{array}$ & $\begin{array}{c}\text { Lee and White } \\
\text { Clotting Times } \\
\text { (Average of 3 Readings) }\end{array}$ \\
\hline $\begin{array}{l}0.3 \mathrm{ml} \text {. saline } \ldots .3 \mathrm{ml} \text { patient's whole blood } \\
0.3\end{array}$ & $\ldots$ & $\begin{array}{c}5 \text { minutes } \\
\text {, }\end{array}$ \\
\hline
\end{tabular}

TABLE III

CLOTTING TIMES ON ADDITION OF PATIENT'S PLASMA OR SERUM TO NORMAL BLOOD

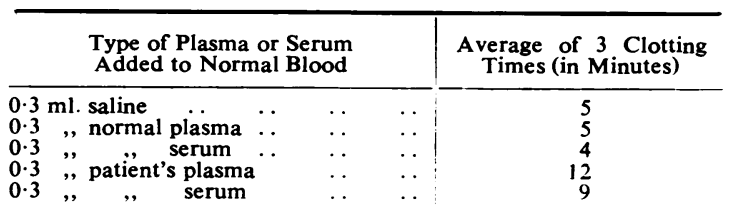

patient's serum and plasma contained the anticoagulant.

Effect of Normal Plasma on Clotting Times of Patient's and Haemophilic Plasma.-It can be seen (Table IV) that the type of response obtained by adding varying percentages of normal plasma to the patient's plasma differs from that obtained by adding normal to haemophilic plasma, for a much larger amount of normal plasma was required in the former instance to produce the same relative fall in the clotting time. Table IV also shows that haemophilic plasma had no effect on the patient's plasma and vice versa. To obtain the results in Table IV $0.1 \mathrm{ml}$. of the plasma mixtures, which were made up immediately before use, was mixed with $0.1 \mathrm{ml}$. of saline and recalcification effected by $\mathbf{M}-40$ calcium chloride after one minute's incubation.

TABLE IV

CLOTTING TIMES OF PLASMA MIXTURES

\begin{tabular}{|c|c|c|c|c|c|c|c|c|c|c|c|c|}
\hline \multirow{2}{*}{$\begin{array}{l}\text { Plasma } \\
\text { Used } \\
\text { as } \\
\text { Sub- } \\
\text { strate }\end{array}$} & \multirow{2}{*}{$\begin{array}{l}\text { Type of } \\
\text { Plasma } \\
\text { Added } \\
\text { to Sub- } \\
\text { strate }\end{array}$} & \multicolumn{11}{|c|}{ Percentage of Plasma Added to Substrate } \\
\hline & & $\begin{array}{l}\text { Sal- } \\
\text { ine }\end{array}$ & & & & & & $\begin{array}{l}66 \\
\text { Tim }\end{array}$ & & & & 100 \\
\hline Patient's & Norn & 13 & 11 & 0 & 10 & 9 & 7 & $5 \frac{1}{2}$ & 4 & $3 \frac{1}{2}$ & $3 \frac{1}{2}$ & $3 \frac{1}{2}$ \\
\hline $\begin{array}{l}\text { aem } \\
\text { phil }\end{array}$ & $\begin{array}{l}\overline{\text { Normal }} \\
\text { Patient's }\end{array}$ & $\begin{array}{l}14 \\
14\end{array}$ & $\begin{array}{r}6 \\
14 \\
\end{array}$ & 13 & 14 & 13 & $\begin{array}{r}3 \\
12\end{array}$ & $\begin{array}{r}3 \\
12\end{array}$ & $\begin{array}{r}3 \\
13\end{array}$ & 22 & $\begin{array}{r}22 \\
13\end{array}$ & $\begin{array}{r}2 \\
13\end{array}$ \\
\hline
\end{tabular}

The results shown in Table $\mathrm{V}$ suggest that the circulating anticoagulant in the patient's plasma was either slowly acting, as Biggs and Macfarlane (1953) have suggested, or that it existed partly as an inactive precursor requiring incubation with some factor in normal plasma for the development of its full capacity.

Plasma Thromboplastin Generation. - Biggs, Douglas, and Macfarlane (1953) have shown that a powerful thromboplastin can be formed by the incubation of a factor present in normal serum antihaemophilic globulin which is present in normal plasma, platelets, and calcium. Using the blood 
TABLE V

RECALCIFICATION TIMES OF SAMPLES OF AN INCUBATING MIXTURE OF EQUAL VOLUMES OF NORMAL AND PATIENT'S PLASMA

\begin{tabular}{l|c|c|c|c|c}
\hline Period of incubation & $1 \mathrm{~min}$. & $10 \mathrm{~min}$. & $30 \mathrm{~min}$. & $1 \mathrm{hr}$. & $2 \mathrm{hr}$. \\
\hline Recalcification time & $4 \mathrm{~min}$. & $7 \mathrm{~min}$. & $8 \mathrm{~min}$. & $8 \mathrm{~min}$. & $10 \mathrm{~min}$. \\
\hline
\end{tabular}

thromboplastin-generation test of these workers (Biggs et al., 1953), Figs. 1 and 2 were obtained. Fig. 1 shows that the patient's platelets are normal in blood thromboplastin formation and that the patient's plasma inhibits the formation of this thromboplastin. Fig. 2 shows that the patient's serum is also inhibitory.

The patient's prothrombin measured by a twostage technique using blood thromboplastin instead of brain thromboplastin was found to be within normal limits, showing that the circulating anticoagulant has no action on blood thromboplastin already generated.

Properties of the Circulating Anticoagulant.-The inhibitor was found to be relatively heat-stable, surviving heat at $56^{\circ} \mathrm{C}$. for 30 minutes and heat at $70^{\circ} \mathrm{C}$. for 10 minutes. It could not be dialysed out of the plasma or serum and was not absorbed by aluminium hydroxide. The active substance was found in the fraction precipitated from either plasma or serum by $\frac{1}{4}$ to $\frac{1}{3}$ saturation with ammonium sulphate. The supernatant fluid when dialysed against normal saline had no inhibitory activity. The euglobulin precipitated from the patient's plasma by dilution 1 in 10 with distilled water and acidification to $p H 5.4$ had no inhibitory activity. Electrophoretic studies showed the circulating anticoagulant to be

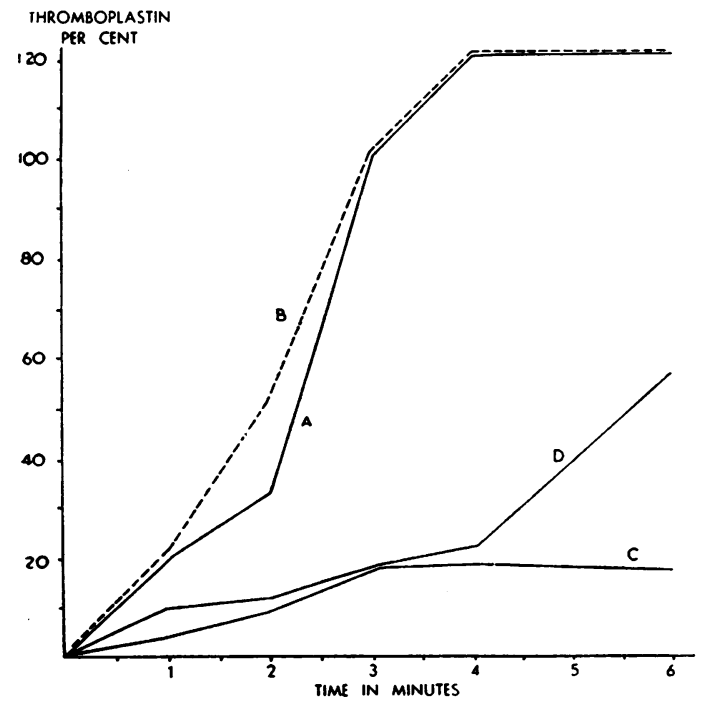

Fig. 1.-The formation of blood thromboplastin from, A, normal alumina-treated plasma, normal platelets, normal serum, and calcium chloride; B, as A, but patient's platelets; C, as A, but calcium chloride; B, as A, but patient's platelets; $90 \%$ as A, but alumina-treated plasma and $10 \%$ patient's alumina-treated plasma.

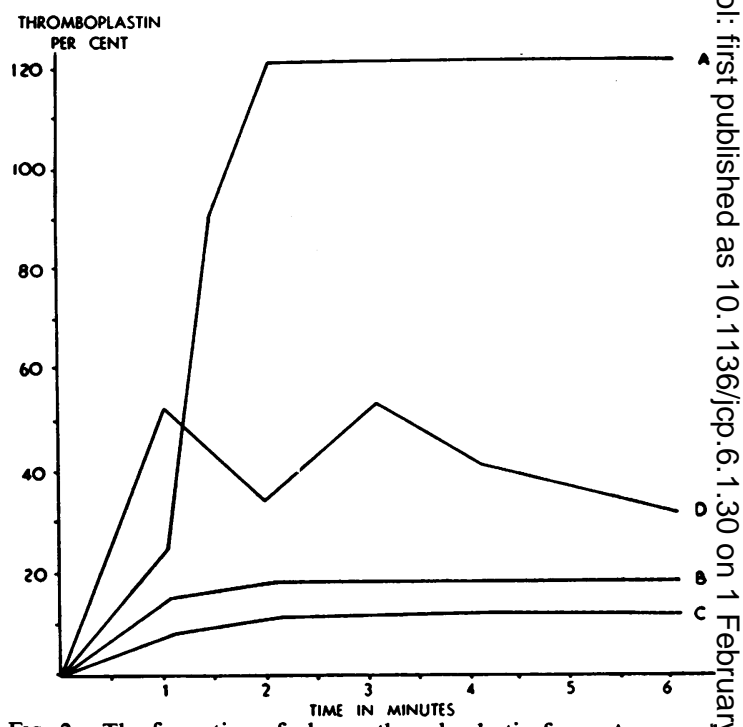

Fig. 2.-The formation of plasma thromboplastin from, A, normak alumina-treated plasma, normal serum, normal platelets, andcalcium chloride; $B$, as $A$, but patient's instead of normako serum; C, as A, but saline instead of normal serum; $D$, as $A$ G but $33 \%$ patient's serum and $66 \%$ normal serum instead of saline.

in the gamma and beta globulin fractions of theo serum; the pattern was normal.

Precipitin tests to antihaemophilic globulin wereo inconclusive.

\section{Discussion}

Pseudo-haemophilia is a rare disease, but $\overrightarrow{\overrightarrow{0}}$ probably occurs more frequently than the smalP number (18) of published cases would indicate In eight of these the diathesis developed within a year of parturition. The remaining cases cons sisted of seven men and three women whose ages varied between 21 and 73 . Two of these were previously healthy women aged 57 and 43 respeci tively (Joules and Macfarlane, 1938; Pons andB Torregrosa, 1952); other cases were associatedb with tuberculous lymphadenopathy (Lozner? Jolliffe, and Taylor, 1940), chronic nephritis and syphilis (Conley, Rathbun, Morse, and Robinson 1948), enlarged lymph nodes due to a reactive hyperplasia of unknown origin (Conley et al. N 1948), myocardial infarction (Singer et al., 1950) and rheumatoid arthritis with amyloid deposits in the lymph nodes (Collins and Ferriman; 1952) ; if the two remaining cases the circulating anti coagulant appeared during the arsenical treatment? of pemphigus (Quick and Stefanini, 1948 ; Dieter; Spooner, and Pohle, 1948).

The appearance of a circulating anticoagulan $\overparen{D}$ in some haemophiliacs following transfusion of injection of blood or blood products containing antihaemophilic globulin has been observed by several workers. Munro (1947), in a study of suclo 
an anticoagulant, concluded from its properties that it was the same substance that had been found earlier by Lozner et al. (1940) in a non-haemophiliac and by Lawrence and Johnson (1942) in a haemophiliac. Since then Biggs and Macfarlane (1953) have investigated a circulating anticoagulant appearing in a woman four months after parturition, and the properties of this agree in every respect with those of the circulating anticoagulant in my patient and in all important points with those reported by Munro (1947), Pons and Torregrosa (1952), Collins and Ferriman (1952), and others. It may therefore be considered established that the circulating anticoagulants complicating haemophilia and present in all cases of pseudo-haemophilia, whether or not associated with pregnancy, are at least of a closely allied nature, if not actually identical. They are found in the globulin fraction of both plasma and serum, are relatively heat-stable, surviving heat at $56^{\circ} \mathrm{C}$. for 30 minutes, and are unrelated to heparin, antithrombin, or " antithromboplastin."

Biggs, Douglas, and Macfarlane (1953) have shown that an active thromboplastic substance, which they call blood thromboplastin, can be formed from the constituents of the blood in vitro without the addition of extraneous tissue extracts. The experiments reported here using the thromboplastin generation test of Biggs et al. (1953) show conclusively that the circulating anticoagulant is directed against the formation of blood thromboplastin and has little or no action against thromboplastin already formed. The anticoagulant, therefore, acts during a very early phase of blood coagulation and would be called an antithromboplastinogen in the terminology of Quick.

The differential diagnosis between haemophilia unassociated with a circulating anticoagulant and pseudo-haemophilia is usually possible on clinical grounds alone. Thus haemophilia usually manifests itself from early infancy, and joint changes are often present at an early age ; there is often a family history, and the condition is excessively rare in women. In contrast, pseudo-haemophilia occurs in adults with no previous or family history of a haemorrhagic diathesis and involves the two sexes equally. The diagnosis should, however, always receive laboratory confirmation. The usual routine tests for haemophilia such as delayed prothrombin consumption and failure of known haemophilic blood to correct the clotting defect are also positive in pseudo-haemophilia, and for the differential diagnosis special tests are necessary. Probably the best of these are the thromboplastin generation test of Biggs et al. (1953), and the ability of small proportions of whole blood, plasma, and serum containing a circulating anticoagulant to prolong the clotting time of normal whole blood or plasma. If the latter test is inconclusive the test plasma should be incubated with normal plasma and the recalcification times of samples removed at intervals noted; if there is then no marked increase at some time within three hours, a circulating anticoagulant can be excluded. In the thromboplastin generation test the serum of a case of pseudo-haemophilia is inactive or inhibitory, unlike the serum of an uncomplicated hasmophiliac, which is active in the formation of blood thromboplastin.

\section{Summary}

A case of haemorrhagic diathesis due to a circulating anticoagulant which differs from heparin, antithrombin, and "antithromboplastin" is described in a previously healthy man aged 82 .

This condition, which is referred to as pseudohaemophilia, is probably not excessively rare and is a disease of adults.

The circulating anticoagulant is present in the globulin fraction of both plasma and serum and is relatively heat-stable, surviving heat at $70^{\circ} \mathrm{C}$. for 10 minutes.

Experiments carried out on blood thromboplastin generation show that the circulating anticoagulant acts by inhibiting the formation of blood thromboplastin, but has little or no action on any thromboplastin already formed.

I would like to thank Mr. G. B. Woodd Walker, under whose care this patient was admitted, and my chief, Dr. R. G. Waller, for their help and encouragement. I am also indebted to Dr. H. E. Archer for the biochemical investigations and Dr. R. G. Macfarlane and Dr. R. Biggs for generously allowing me access to the proofs of their book. Dr. R. Biggs and Dr. S. Douglas were kind enough to read the manuscript and made many helpful suggestions.

While making this investigation the author received a grant from the Dan Mason Research Foundation.

$$
\text { REFERENCES }
$$

Biggs, R., and Douglas, A. S. (1953). Journal of Clinical Pathology, 6, 15 . and Macfarlane, R. G. (1953). Human Blood Coagulation and its Disorders. Blackwell, Oxford. In the press.

Collins, I. S., and Ferriman, D. G. (1952). Lancet, 2, 712.

Conley, C. L.. Rathbun, H. K., Morse. W. I., and Robinson, J. E. (1948). Bull. Johns Hopk. Hosp., 83, 288 .

Dieter, D. G., Spooner, M., and Poh'e. F. J. (1949). Rlood, 4, 120.

Joules, H., and Macfarlane, R. G. (1938). Lancet, 1, 715.

Lawrence, J S.. and Johnson, J. B. (1942). Trans. Amer. clin. clim. Ass., 57, 223.

Lozner. E. L., Jolliffe, L. S., and Taylor, F. H. L. (1940). Amer. J. med. Sci, 199, 318.

Merskey. C. (1950). Journal of Clinical Pathology, 3, 301.

Munro, F. L. (1946). J. clin. Invest., 25, 814.

Munro, F. L. (1946). J. clin. Invest., 25, 814 .
Owen, C. A., and Bollman, J. L. (1948). Proc. Soc. exp. Biol., N.Y., 67, 367 .

Pons, E. R., and Torregrosa, M. V. de (1952). Blood, 7, 20.

Quick. A. J., and Stefanini, M. (1948). Proc. Soc. exp. Biol., N.Y., 67,111 .

Singer, K., Mond, E., Hyman, J., and Levy, R. C. (1950). Blood, 5, 1135. 